\title{
Erratum to: Indigenous frameworks for observing and responding to climate change in Alaska
}

\author{
Patricia Cochran • Orville H. Huntington • Caleb Pungowiyi • \\ Stanley Tom • F. Stuart Chapin III • Henry P. Huntington • \\ Nancy G. Maynard • Sarah F. Trainor
}

Published online: 24 June 2014

(C) Springer Science+Business Media Dordrecht 2014

\section{Climatic Change (2013) 120:557-567 \\ DOI 10.1007/s10584-013-0735-2}

In section 5, item 1 of this article it is stated that:

A recent shift in decision-making authority from the politically appointed Board of Game to the Subsistence Division of the Alaska Department of Fish and Game should make these decisions about hunting regulations more responsive to local observations and needs. We now recognize that this shift in regulatory authority to ADF\&G never occurred. We hereby correct this error so that wildlife users in Alaska do not come to ADF\&G with expectations that this agency has authority to adjust hunting regulations to accommodate climate change.

The online version of the original article can be found at http://dx.doi.org/10.1007/s10584-013-0735-2.

P. Cochran

Alaska Native Science Commission, P.O. Box 244305, Anchorage, AK 99524, USA

O. H. Huntington

Wildlife and Parks, Tanana Chiefs Conference, 122 1st Avenue, Ste 600, Fairbanks, AK 99701, USA

C. Pungowiyi

Savoonga, AK, USA

S. Tom

Newtok Village Council, P.O. Box 5545, Newtok, AK 99559, USA

F. S. Chapin III $(\bowtie)$

Institute of Arctic Biology, University of Alaska Fairbanks, Fairbanks, AK 99775, USA

e-mail: terry.chapin@alaska.edu

H. P. Huntington

23834 Clearing Drive, Eagle River, AK 99577, USA

N. G. Maynard

Cryospheric Sciences Branch, NASA Goddard Space Flight Center, Greenbelt, MD 20771, USA

S. F. Trainor

Alaska Center for Climate Assessment and Policy, University of Alaska Fairbanks, Fairbanks, AK 99775, USA 